\title{
The Translation Features of the Connotative Vocabulary
}

\author{
Valentyna Karpiuk ${ }^{1, *}$ Vita Hamaniuk $^{1}$
}

\author{
${ }^{1}$ Kryvyi Rih State Pedagogical University, Ukraine \\ *Corresponding author.Email: karpiukval2017@gmail.com
}

\begin{abstract}
The article considers the problem of translating a connotative vocabulary from German into Ukrainian, defines the concept of a connotation and its characteristic features, presents the main translation methods of and the motives for their use. The importance and complexity of achieving equivalence in the process of translating a connotative vocabulary has been substantiated. The contradictions, that have identified the linguistic problem of choosing a particular translation method to achieve a connotative equivalence, are identified. The theoretical foundations of the study are described. It has been established that the degree of the translation equivalence also depends on the extent to which the norms of the target language can be objectively observed in the translation. In this respect, the criteria for translation into the native language are naturally higher than the corresponding criteria for translation from the native language into the foreign one. It is noted that the connotation can accompany the semantics of the unit at all levels of the language and are actualized in the language by colouring the speech actions of a person, thus performing the specific function of the language. It is emphasized that one of the determining factors of an equivalent translation is the connotative equivalence, namely, the connotations that are used in the text by the nature of verbalisation. (In particular, through a specific choice between a synonymous or quasi-synonymous way of expressing expression), by style, sociolect and geographic dimension, frequency, etc. The main requirements that determine the communicative equivalence of a new text in relation to the original are presented, as well as the classification of connotative dimensions related to a translation, which help to classify connotative meanings. The research results are summarized and the prospects for further research are indicated. It is noted that the content of the text is the realization of the author's communicative intention, which is formed under the influence of a number of extra linguistic factors. It can be understood only by correlating linguistic meanings with extra linguistic factors relevant to each language situation, and correct translation of the original text into the translated language is impossible without conveying the author's intentions, feelings, emotions, additional associations that the word evokes in the minds of native speakers of its connotative meaning.
\end{abstract}

Keywords: translation, equivalent translation, connotation, connotative meaning, transformation, connotative equivalence.

\section{1. ВСТУП}

Сучасні проблеми глобалізації культури, розвиток i ускладнення міжкультурних комунікацій, зростання значущості культурних кодів розширюють межі перекладу, виявляючи його роль не тільки у загальноприйнятому сенсі, як мовної події, а й в широкому сенсі - як події культурної, як переміщення тексту 3 однієї культурної парадигми в іншу. Умови інтернаціоналізації усіх сфер життя спонукають до міжкультурної взаємодії, що актуалізує потребу міжнародного взаєморозуміння. Завдяки стрімкій інтенсифікації міжнародних контактів у наш час перекладацька діяльність у всіх її проявах набуває все більшого значення.

Виходячи 3 багатогранності та багатоаспектності процесу перекладу, адже він складає суттєвий відсоток від усіх дій у сфері інтелектуальної діяльності, слід зауважити, що проблеми перекладу пов'язані не з периферійними явищами, коли перекладацька творчість зводиться лише до нетривіальних унікальних рішень, 
необхідних у таких “екзотичних” випадках, як переклад образів, каламбурів, жаргонізмів, конотативно забарвленої лексики i т.і., а 3 використанням усіх ресурсів мови для досягнення завдань міжмовної комунікації.

Розглядаючи “переклад” як неоднозначне лінгвістичне явище та як особливий вид духовної діяльності, є доцільним і закономірним визнання того, що з одного боку, він описує процес, під час якого зміст та особливості стилістичної сторони оригіналу відтворюються засобами іншої мови. 3 іншого боку, це фактичний продукт цього процесу, тобто текст або усне висловлювання цільовою мовою.

Переклад завжди грав важливу роль у культурній історії окремих народів та світовій культурі в цілому. Бо мова $\epsilon$ віддзеркаленням культури; вона відображає ідентичність людей, їхнє світосприйняття та їхні традиції. Зрозуміло, що люди не можуть опанувати всіх мов світу, але зрозуміти іншу культуру, традиції та світ можливо через переклад, який дозволяє наблизитися до “чужого", сприйняти його й засвоїти як відоме, “своє”. Щоб переклад був якісним і повноцінно відтворював текст i контекст оригіналу, перекладач повинен знати особливості повсякденного життя і культури як мови, з якої, так і мови, якою здійснюється переклад. Особливе місце в процесі перекладу посідають труднощі пов'язані зі способами i можливостями еквівалентного перекладу конотативно забарвленої лексики.

Що стосується проблеми перекладу як феномена національно-культурної комунікації, доводиться констатувати іiі недостатню розробленість. Метою $є$ виявлення сутності перекладу як механізму смислової трансформації, інтерпретації і трансляції, репрезентованих насамперед в комунікації. У контексті національно-культурної специфіки перекладу особливе місце займає аналіз особливостей i способів передачі, виявлення i визначення категорії конотації в зв'язку з ії активним впливом на формування асоціативно-образного змісту, який доповнює, коригує, видозмінює об'єктивне значення певних груп одиниць мови і тим самим впливає на процес і результат перекладу. Втрата образності під час перекладу спричиняє порушення асоціативного фону тексту і абсолютно природно виникає проблема відтворення цього фону засобами мови, що неможливо без проникнення в системно-структурну архітектоніку лінгвістичного об'єкта підвищеної складності - потенціалу конотативного компонента мовних одиниць.

Продукт перекладу (трансформований текст) являє собою певне об'єктивоване явище, яке є продуктом кореляції свідомостей комунікантів. Діяльність суб'єктів перекладу: автора, читача, перекладача може бути віднесена до онтологічних основ перекладу як смислової трансформації, оскільки кожен 3 них є і автором, і реципієнтом, i інтерпретатором світу, об'єктивує особисті, індивідуальні смисли, сприймаючи, витлумачуючи і транслюючи загальні смисли своєї i чужої культури. Автор і читач здійснюють функцію перекладачів в широкому сенсі. Перекладач у власному розумінні один; функціонально це - суб'єкт-посередник в міжмовній комунікації, який здійснює медіацію. Характер взаємодії суб'єктів перекладу визначає його рівень (ступінь трансформаціi).

Протиріччя між намаганням зберегти в процесі перекладу емоційно-оціночно-експресивностілістічний ефект конотації, яка має національнокультурну специфіку, і переважно неможливістю прямого відтворення тексту оригіналу в тексті перекладу визначають лінгвістичну проблему еквівалентного перекладу коннотативно забарвленої лексики.

Загальні аспекти перекладознавства, зокрема питання адекватного перекладу, знайшли послідовне висвітлення в роботах В. Виноградова, Н. Гарбовського, Р. Зорівчак, В. Комісарова, Л. Латишева, K. Kaindl, W. Koller, C. Nord, E. Nida, R. Stolze, K. Reiß und Hans J. Vermeer, W. Wills та інших.

Питання конотації та конотативно забарвленої лексики теоретично обгрунтовано в працях багатьох вітчизняних та зарубіжних учених, серед яких варто відзначити таких, як: І. Арнольд, В. Говердовский, М. Комлєв, М. Кожина, В. Телія, E. Donalis, H. Elsen, W. Fleischer, W. Koller, T. Schippan та інших. Специфічність виявлення конотативно забарвленої лексики полягає в тому, що досить важко буває окреслити межі денотативного і конотативного значення. У теорії денотативна і конотативна величини є величинами різного порядку; вони несумірні. Насправді вони взаємопроникні; далеко не завжди можна вирішити, де закінчується денотативне i починається конотативне значення [4]. I хоча ця проблема не $\epsilon$ новою, вона потребує більш грунтовного дослідження, адже однозначних шляхів ії розв'язання не запропоновано. 
У науковій літературі термін “еквівалентний переклад” є досить поширений і його тлумачення відрізняються деякою неоднозначністю, однак незаперечним $\epsilon$ той факт, що еквівалентним вважається такий переклад, у якому текст оригіналу та текст мовою перекладу є подібними і досягають однакової комунікативної мети в межах відповідної культури. Особливу увагу проблемі адекватного перекладу приділяє у своїх дослідженнях W. Koller: "Es gibt kaum eine Frage in der jahrhundertealten Auseinandersetzung mit dem Übersetzen, die intensiver und kontroverser diskutiert worden ist, als die der theoretischen und praktischen Möglichkeit oder Unmöglichkeit des Übersetzens", [9].

Метою статті $\epsilon$ висвітлення основних аспектів та особливостей еквівалентного перекладу конотативно забарвленої лексики у сучасній лінгвістиці.

\section{2. РЕЗУЛЬТАТИ ТА ОБГОВОРЕННЯ}

Існує безліч визначень поняття "переклад", згідно з якими, можна сказати, що переклад є будьяким перетворенням вихідного тексту в цільовий текст мовою перекладу. Переклад це не просто відображення вихідного тексту, адже важливу роль в цьому процесі відіграє функціональна сторона перекладу. Іншими словами, вихідний текст визначає його цільове використання, тому переклад передбачає аналіз i визначення найголовнішого, на що слід звернути увагу, або виокремити, для кого і з якою метою виконується даний переклад. Підтвердження цьому знаходимо у дослідженнях M. Kadric, K. Kaindl, und M. Kaiser-Cooke: “Übersetzen heißt, einen Zieltext über Sprach- und Kulturbarrieren hinweg zu erstellen. Die Realisation der verschiedenen Dimensionen des Zieltextes (Inhalt, Form, Stil, Wirkung etc.) hängt von der intendierten Funktion, die dieser in der Zielkultur erfüllen soll, ab. Diese Funktion ist es auch, die die Art der Anbindung an den Ausgangstext bestimmt" [8].

Перекладом називається процес і результат створення на основі вихідного тексту рівноцінного йому в комунікативному відношенні тексту мовою перекладу. При цьому комунікативна рівноцінність, або еквівалентність, розуміється як така якість тексту перекладу, яка дозволяє йому виступати в процесі спілкування носіїв різних мов як повноправна заміна вихідного тексту (оригіналу) в сфері дії мови перекладу. Також не менш важливою складовою будь-якого перекладу $\epsilon$ перетворення елементів (символів) вихідної мови через символи цільової мови, зокрема наявність відчуття ідентичності між символами мови оригіналу та мови перекладу $[11$, с. 87]. Не останню роль у якості еквівалентного перекладу відіграє контекст (змістова точність, збереження якості мови оригіналу, мовно-стилістичних, текстових i прагматичних особливостей, як відповідностей, так і відміностей, які повязані або підпорядковані контексту). Так, на думку W. Koller визначальними для еквівалентного перекладу $\epsilon$ денотативна еквівалентність (außersprachlicher Sachverhalt), конотативна еквівалентність (Art der Verbalisierung), текстовонормативна еквівалентність (Text- und Sprachnormen (Gebrauchsnormen)), прагматична еквівалентність (Empfänger (Leser)-Bezug), формально-естетична еквівалентність (ästhetische, formale und "individualistische" Eigenschaften des $A T)[11$, c. 219].

Комунікативна еквівалентність нового тексту по відношенню до оригіналу забезпечується виконанням трьох основних вимог:

- текст перекладу повинен в якомога повнішому обсязі передавати зміст оригіналу, що перш за все означає неприпустимість довільного випущення або додавання інформації, як i неприпустимість передачі менш суттєвої інформації за рахунок більш істотної;

- текст перекладу повинен відповідати нормам мови перекладу, тому що їх порушення щонайменше створює перешкоди для сприйняття інформації, а іноді веде й до ії спотворення;

- текст перекладу повинен бути відповідним до оригіналу за своїм обсягом, що забезпечує подібність стилістичного ефекту 3 точки зору лаконічності.

Виконання зазначених вимог до тексту перекладу часто пов'язано з подоланням різного роду об'єктивно існуючих труднощів. При цьому, у зв'язку з відмінностями мовних систем мови оригіналу і мови перекладу, відмінностями в культурі носіїв двох мов й іншими чинниками практично виключається стовідсоткова передача інформації під час перекладу. До речі, історична, індивідуальна та соціальна ситуація має великий вплив на переклад, тому тут можемо говорити лише про ту чи іншу міру подібності інформації, досяжної в даних умовах.

Ступінь еквівалентності перекладу залежить також і від того, наскільки в перекладі можуть бути об'єктивно дотримані норми мови перекладу. В цьому відношенні критерії перекладу рідною 
мовою, природно, вище, ніж відповідні критерії при перекладі з рідної мови іноземною.

Разом $з$ тим, не повинно складатися враження, ніби оптимальна ступінь еквівалентності перекладу рідною мовою передбачає лише один варіант перекладу, єдино можливий і абсолютно бездоганний. Оптимально еквівалентний переклад означає лише, що в ньому відбилося правильне розуміння оригіналу і для його перевираження мовою перекладу знайдені такі засоби, які, поряд 3 іншими, синонімічними засобами вираження, виключають змістові неточності й викривлення, а також нормативні похибки: орфографічні, пунктуаційні, лексико-граматичні та стилістичні.

Надзвичайно складно отримати еквівалентний переклад конотативно забарвленої лексики, яка містить у своїй семантиці національно-культурний компонент. Поняття конотації має довгу й суперечливу історію: науковці, які ведуть дослідження в цій сфері вказують на різні теорії конотацій, найбільш поширеними серед яких є: семіотична (Л. Сльмслєв, С. Ульман, Р. Барт), стилістична (Е. Азнаурова, К. Долінін, Е. Шендельс), психологічна (А. Леонтьєв, Портер), філософська (Алстон), логічна (Огден, Річардс), семантична (І. Арнольд, В. Стернін, В. Телія, В. Шаховський). Термін “конотація” $є$ одним з найменш зрозумілих, оскільки сфера його вживання продовжує поширюватися і все більше втрачає чіткі обмежувальні контури. Деяка “дифузність” поняття конотація пов'язана певною мірою 3 існуючими в сучасній лінгвістиці двома основними підходами до сутності цього явища. 3 одного боку, семантика слова поряд 3 сигнификативно-денотативним значенням включає і конотативне, і так зване “внутрішньо лінгвістичне”, тобто конотація розглядається як частина семантичного значення слова. Однак правомірна й інша точка зору, згідно 3 якою конотація $\epsilon$ не що інше, як асоціативні та емоційно-оціночно-експресивно-стілістічні значення, що виникають в процесі мовлення під впливом контексту.

Конотація не $є$ елементом матеріальної структури слова-знака. Її компоненти створюються в процесі сприйняття слів-знаків. Зв'язок мовних елементів з культурою обумовлює та сприяє опису культурних реалій, де знання культурної конотації набуває виняткової важливості й актуальності. Комплекс компонентів значення іноземного слова, яке засвоєно на базі реалій мови оригіналу, не відповідає комплексу, який відомий середньостатистичному носію цієї іноземної мови. Різниця між рівноцінними словами різних мов криїться в різниці місця в системі інших слів. Отже, лексико-граматичний зміст двох слів різних мов ніколи повністю не співпадає ні в семасіологічному, а ні в ономасіологічному плані. Намагання зарубіжних та вітчизняних вчених уточнити об'єкт, який визначається цим терміном, спричинили появу великої кількості визначень конотації, аналіз яких засвідчив відсутність однозначності щодо розуміння сутності, природи конотації та зрозумілого тлумачення ії семантичної структури. Різноманітність підходів до вивчення конотації допомогають розкрити іiі властивості. Так, наприклад, серед характерних ознак конотації перш за все вказують на ознаку додатковості до денотативного аспекту значення. Саме такої думки дотимується в своєму дослідженні Bettina Felicitas Birk: "Konnotation zeigt auf sprachlicher Ebene die auf Emotionen beruhende Bewertung des außersprachlichen Objekts durch den Sprachbenutzer. Konnotation ist demnach die evaluative Komponente eines sprachlichen Ausdrucks, die zu seiner Denotation hinzukommen kann" [3, с. 94]. Одностайні дослідники в тому, що конотація другорядна по відношенню до денотації, а також у визнанні іiі зв'язку 3 емоційно-оціночноекспесивно інформацією, яку, все ж таки, частіше відносять до стилістичної. Більше того, французькі лінгвісти, наприклад, відносять до конотації усі регіональні особливості, помилки в мові й мовні аномалії, значно розширюючи її поняттєве поле.

Конотація належить до ідеального світу. Вона не описує світ на відміну від логіко-предметних значень, вона описує емоційне ставлення людини до світу, відображає ці відношення в семантиці слова й фразеологічних одиниць через емотивні семи. Таким чином, конотація - це той компонент семантики мовної одиниці, за допомогою якого виражається стан мовця й обумовлене ним ставлення до адресату, об'єкту й предмету мови, ситуації, в якій здійснюється дане мовне спілкування i який називається в логікопредметному значенні цієї одиниці [15, с. 13-14].

Конотація може супроводжувати семантику одиниць усіх рівнів мови i, актуалізуючись у мові, забарвлюючи мовні дії людини, виконувати таким чином специфічну функцію мови. Денотація і конотація беруть спільну участь в номінації, де денотація відображає суттєві понятійні ознаки, а конотація - їх оцінку. Дієслова лексикосемантичної групи “фізичного знищення": abschaffen (найбільш нейтральне значення, його конотативне навантаження виражається 6 
значенні " $j$-n umbringen), abkochen (семантика дієслова полягає не тільки у фізичному, а й y моральному знищенні), abrasieren ("dem Erdboden gleichmachen” відбувається в результаті метафоричного переносу), abfangen (експресивність дієслова досягається тим, щзо вказується знарядд, за допомогою якого відбувається знищення), abschlachten (жорстоке знищення людини подібно до того, як передчасно або вимушено колють $i$ забивають худобу, використання у розмовно-побутовому стилі) відзначаються високим рівнем інтенсивності, мають різну конотативну забарвленість [6, с. 5]. Логічна семантика всіх цих слів одна й та сама, а от конотації і стилістична приналежність - різні, звідси й ефект від цих слів, тобто реакції на них тих, хто говорить, різні.

Виходячи з аналізу сутності і характеристики поняття “конотація”, слід розкрити й представити відповідні способи перекладу конотативно забарвленої лексики та визначити найбільш поширені 3 них. Під час перекладу виникає, 3 одного боку, необхідність підкреслити емоційнооціночно-експресивно-стилістичний ефект, додаткове значення, асоціації, які є типовими для носія вихідної мови, а з іншого, досягти найвищого ступеня еквівалентності засобами мови перекладу. Найбільш відповідним способом перекладу даного виду лексичних одиниць можуть бути перекладацькі трансформації - перебудови, за допомогою яких здійснюється перехід від одиниць мови оригіналу до одиниць мови перекладу. Як відомо, трансформації є основою більшості засобів перекладу. Вони полягають у заміні формальних та семантичних характеристик мовної одиниці. Перекладацькі трансформації можуть бути використані у тих випадках, коли відсутні регулярні відповідники в мові перекладу, або вони не можуть бути використаними в умовах контексту. Наприклад, Das für seine zeitreisende Seifenoper beliebte Theater ,Adolf Südknecht” startet ins neue Jahr mit einer Glotzkasten-Offensive, die sich gewaschen hat. Gleich vier Projekte starten zum Jahresanfang mit einem verheißungsvollen Auftakt in das zehnte Geburtstagsjahr seit der ImproschauGründung. Театр “Адольф Зюдкнехт”, популярний завдяки мандрівній мильній опері, починає новий рік із неймовірного наступу на телебачення. До десятиріччя заснування Імпрошоу стартують на початку року одразу чотири проекти, які мають далекосяжні перспективи. Даний приклад демонструє застосування таких способів перекладу як трансформаційний переклад, заміну, додавання, опущення, транслітерацію, генералізацію, наближений переклад, компенсацію, смислове узгодження.

Вибір того чи іншого способу трансфрмацій має бути вмотивованим. До найсуттєвіших мотивів застосування перекладацьких трансформацій за А.Ф. Архіповим [1] належать:

- прагнення уникнути у мові перекладу так званих “буквалізмів";

- необхідність подолати розбіжності мовних норм;

- прагнення ідіоматизувати переклад, тобто використовувати вирази й конструкції, найбільш уживані в українській мові у певних контекстах, ситуаціях, стилістичних різновидах текстів;

- прагнення уникнути неприродності, неясності й нелогічності вираження;

- прагнення уникнути словотворчих моделей, які не характерні для мови перекладу;

- прагнення до більш компактного варіанту перекладу;

- прагнення донести до реципієнта важливу фонову інформацію чи зняти надлишкову;

- прагнення відтворити гру слів, образність та інші стилістичні фігури, які важко перекласти.

Як було зазначено вище, одним із визначальних факторів еквівалентного перекладу $\epsilon$ конотативна еквівалентність, яка, на думку W. Koller, визначається саме як конотації, що використовуються в тексті відповідно до характеру вербалізації відносно стилю, соціолекту і географічного виміру, частотності і т.і. (зокрема, шляхом специфічного вибору між синонімічним або квазі-синонімічним способом вираження експресіi): “wenn „,mit der spezifischen Art der sprachlichen Erfassung des Denotats [...] zusätzliche konnotative Werte vermittelt [...]" bzw. wenn "die im Text durch die Art der Verbalisierung (insbesondere: durch spezifische Auswahl unter synonymischen und quasi-synonymischen Ausdrucksmöglichkeiten) [...] Konnotationen bezüglich Stilschicht, soziolektale und geographische Dimension, Frequenz etc." evoziert werden" [12, с. 240]. За Г. Бусманном [2, с. 368], конотації $\epsilon$ “компонентами значення мовного виразу, що покриває його основне значення”, наприклад, емоційний, стилістичний та регіональний компоненти. Так, слово Führer поряд 3 концептуальним значенням, пов'язане 3 Третім Рейхом. Еквівалентна конотація належить до проблем перекладу, яку можна розв'язати лише приблизно, тобто зробити приблизний переклад, 
що робить ще більш цікавим і важливим мовний i текстуальний аналіз окремо взятих конотативно забарвлених лексичних і синтагматичних сфер.

Конотативність 3'являється як наслідок неоднорідності мови. Мовні засоби (слова, синтагми, речення) підпорядковуються різним мовним рівням, вони відрізняються за частотністю вживання, сферою використання, стилістичним ефектом; вони можуть обмежуватися групою користувачів. Go to hell! в англійській мові, Iди до бicy! в українській може вважатися як денотативний прямий еквівалент Fahr zur Hölle!, але насправді конотативний ефект буде зовсім різний. Слід також зазначити, що розглядаючи конотативне значення, необхідно усвідомлювати різницю між релевантними i нерелевантними конотативними значеннями на рівні тексту. Незалежно від того, яка саме лексична одиниця використовується: Metzger, Fleischer чи Fleischhauer, завдання перекладача передбачає аналіз тексту, визначення й оцінку конотативних значень мовних одиниць, їх ієрархії з точки зору доречності їх збереження в тексті мови перекладу.

Стиль тексту утворюється зі специфіки тексту, частотності, розподілу i комбінаторності конотативно забарвлених мовних одиниць на рівні слова, синтагми, речення та понадреченнєвого рівня. Стилістичне значення - це закріплена за лінійно-просодичним комплексом частина семантики, яка відображає соціальний припис його вживання, яке існує в свідомості носія мови. На відміну від денотативного та емоційного, стилістичне значення не $\epsilon$ потенційно інформативним. Стилістичне значення будь-якої одиниці мови утворюється з того, що воно досить вибірково вживається в різних мовних утвореннях за наявною загальною або відомою стилістичною моделлю, і $з$ того, що середньостатистичний носій мови не лише правильно в стилістичному відношенні обирає слово, але й нерідко може пояснити свій вибір. Стилістичні значення та їх системи історично з'являються й широко розвиваються пізніше денотативних. Крім того, конотативне значення мають не тільки окремі слова, але й синтагми й речення, прикладом чого слугує фахова мова: забарвленими є не тільки лексичні одиниці, але й синтаксис фахових текстів. Як один 3 показових прикладів забарвлення $\epsilon$ використання географічно маркованих лексичних одиниць і навіть синтаксичних структур. Так, наприклад, утворення Perfekt c sein або haben: Ich bin gelegen [süddt. Raum] однозначно характеризує особу, яка використовує певне допоміжне дієслово як представника певного регіону. 3 іншого боку, нейтральність щодо використання конотативно маркованих лексичних одиниць $\epsilon$ засобом створення стилю. Тож, наприклад, стилю текстів науково-технічної сфери властива, як правило, стилістична нейтральність щодо більшості конотативних значень.

Причиною, яка обумовлює, проблеми стилістичного перекладу $\epsilon$ те, що системи конотативних значень, які мають стилістичну забарвленість, не співпадають повністю / не мають повної відповідності в різних мовах. Наприклад, Damit verdienen wir keine goldene Nase. - На изьму ми не розбагатісмо (стилістична нейтралізація). Der nationale Hader bringt den Völkern unsägliches Leid - Національна ворожнеча приречує народи на небачені страждання (стилістична сnеціiалізація). Завдання перекладача полягає в тому, щоби реалізувати на рівні тексту в мові перекладу такі мовно-стилістичні можливості, які можуть функціонувати як оптимальні конотативні відповідники. Рішення щодо вибору певного відповідника залежить, з одного боку, від наявних мовно-стилістичних можливостей, з іншого боку, від ієрархії значень, які перекладач створить виходячи $з$ ієрархії відповідного тексту та вимог еквівалентності. Якщо в процесі перекладу 3'ясовується, що у мовної одиниці відсутнє конотативне значення, то воно може бути створено за рахунок коментаря або через опис. Це особливо стосується текстів, в яких конотативне значення виконує важливу стилістичну функцію (соціолекти або діалекти), i, якщо не знайти відповідного рішення, то текст втрачає свою естетичну і художню цінність.

На допомогу перекладачеві W. Koller [9, с. 245] пропонує вісім конотативних вимірів, що стосуються перекладу. Вони допомагають класифікувати конотативні значення:

а) конотації стильового шару (+ вишуканий, + поетичний, + нормальна мова, + розмовна + вульгарна): sterben, entschlafen, das Zeitliche segnen, [für immer] die Augen schließen, verrecken, krepieren, abkratzen, die Patschen strecken; trinken, saufen, tschechern, piperln; Fernsehgerät, TV-Gerät, Fernseher, Glotzkasten, Flimmerkiste; Flugzeug, Fluggerät, Flieger; sehr gut, ausgezeichnet, super;

б) конотації соціального (групового) використання мови (+ мова робітничого класу, + студентська мова, + мова освіченого середнього класу): Jugendsprachlich: geil, mega(geil), affengeil, megaaffengeil, cool, megacool, gigacool; Personencharakterisierung im Theater: Der Hierlinger Ferdinand: Aber gern, sehr gern! Zu 
charmant, gnädige Frau. Die Mutter: lächelt verlegen Aber oh bitte! Zu Valerie Die Dame kommen doch auch mit? (Ödon v. Horvath, Geschichten aus dem Wienerwald);

в) конотації географічного розподілу або підпорядкування(+ надрегіональна, + швабська, + австрійська): Austriazismen: Aprikosen vs. Marillen; Tomaten vs. Paradeiser; Brötchen vs. Semmel; Quarkklößchen vs. Topfenknödel etc.; Figurensprache: Hür mal, Smolt, un ihr annern Lüd! Wer nu'n verstännigen Kierl is, der geht naa Hus un schert sich nich mihr um Revolution und stört hier nich de Ordnung;

г) конотації медійного середовища (+ письмова мова, + розмовна мова): Komplexere Syntax, insbesondere Hypotaxe in der geschriebenen vs. Parataxe und elliptischer Sprachgebrauch in gesprochener Sprache; Verwendung unterschiedl. Zeiten: Präteritum (ging) vs. Perfekt (bin gegangen) etc.;

д) конотації 3 стилістичним ефектом (+ застарілий, + піднесений, + модний, + евфемістичний, + яскравий, + живописний): Im Kinderanfall unserer Stadtgemeinde ist eine hierorts wohnhafte, noch unbeschulte Minderjährige aktenkundig, welche durch ihre unübliche Kopfbedeckung gewohnheitsmäßig Rotkäppchen genannt zu werden pflegt. Der Mutter besagter R. wurde seitens ihrer Mutter ein Schreiben zustellig gemacht, in welchem dieselbe Mitteilung ihrer Krankheit und Pflegebedürftigkeit machte;

е) конотації частотності (+ вживана, + мало вживана): Unterschiede bezügl. der Verwendung von Fremdwörtern, Komposita etc.; Häme vs. Schadenfreude;

є) конотації сфери застосування (+ загальна мова, + технічна мова, + мова медичної сфери): Information für den Arzt: akute Zervizitis, akute oder subakute rezidivierende Entzündungen des Genitalbereiches, anamnestisch bekannter infizierter Abort, postpartale Endometritis [...];

Information für den Patienten: akute oder subakute wiederholt aufgetretene Entzündungen der Geschlechtsorgane, fieberhafte Fehlgeburt und/oder Entzündung der Gebärmutterschleimhaut [...];

3) конотації рейтингу (+ позитивний рейтинг, + негативний рейтинг, + іронічний коментар): Bei dieser Arbeit hast du dir auch nicht gerade ein Bein ausgerissen vs. Bei dieserArbeit hast du dich nicht gerade überanstrengt vs. Mit dieser Arbeit hast du es dir ein bißchen zu leicht gemacht.
Категорія конотативного значення відповідно еквівалентності є досить складною. Очевидно, що вона включає мовні, історичні, узагальнено соціолінгвістичні та стилістичні явища. Тому вкрай складно запропоновути переклад, який би враховув всі можливі смисли різної природи. Слід зауважити, що у зв'язку 3 конотативною еквівалентністю не йдеться ані про будь-який тип еквівалентності, ані про конкретний процес перекладу, за допомогою яких міг бути досягнутий відповідний тип еквівалентності. Перекладачі повинні керуватися своїми відчуттями, спиратися на досвід та знання.

\section{3. ВИСНОВКИ ТА ПЕРСПЕКТИВИ ПОДАЛЬШИХ ДОСЛІДЖЕНЬ}

Роль конотативної лексики дуже важлива, без неї не може обійтися жодна мова, оскільки це необхідні засоби вдосконалення і гнучкості мовної культури, засоби, за допомогою яких в об'єктивну інформацію, відображену за допомогою слів, включається компонент суб'єктивної оцінки, емотивного забарвлення, маркування іншої природи. Тож очевидно, що конотація виступає як складний за своєю суттю макрокомпонент, що складається 3 власне експресивного, емоційного, оцінного, стилістичного конотативних компонентів семантичної структури слів і висловлювань.

Таким чином, можна констатувати, що конотація - це явище, яке включає в себе і мовні дані, які не залежать від людини, але допомагають їй аналізувати й класифікувати повідомлення, що надходять, і різного роду фонові асоціації, як от: почуття, емоції, образи, що виникають в процесі комунікації. При цьому слід зауважити, що в структурі конотації незмінно виділяються в тому чи іншому поєднанні такі типи інформації: емоційна, оцінна, естетична, експресивна i стилістична.

Цілком природно, що при передачі образної конотації на різних лінгвістичних рівнях номенклатура перекладацьких трансформацій i частотність використання конкретних прийомів буде різною, що й становить сутність й водночас складність роботи перекладача.

3 метою передати образні авторські перетворення 3 мови джерела мовою перекладу 3 усього арсеналу перекладацьких засобів найбільш часто перекладач використовує трансформаційний переклад, заміну, додавання, опущення, 
роз'яснювальний переклад, наближений переклад, компенсацію.

Отже, узагальнюючи вище сказане, можемо зазначити, що сенс перекладу мовного твору не зводиться до перекладу значень мовних одиниць, які його утворюють. Будучи реалізацією комунікативного наміру автора тексту, що формується під впливом ряду екстралінгвістичних факторів, зміст тексту може бути зрозумілий тільки при співвіднесенні мовних значень 3 екстралінгвістичними факторами, релевантними для кожної мовної ситуації, і правильний переклад тексту оригіналу мовою перекладу неможливий без передачі намірів автора, почуттів, емоцій, додаткових асоціацій, які слово викликає в свідомості носіїв даної мови, тобто його конотативного значення.

Оскільки знаки мови, як уже зазначалося, можуть справляти на людей різне враження позитивне, негативне або нейтральне, мати на них різний вплив, викликати ту чи іншу реакцію, в залежності від “фонових знань” людей, які говорять різними іноземними мовами, дуже важливо в процесі перекладу враховувати прагматику тексту. Лексичні одиниці двох різних мов, повністю збігаючись за своїм референціальним значенням, можуть розрізнятися за стилістичною характеристикою, емоційним забарвленням, регістром, тобто за прагматичними параметрами. Багато що зрозуміле й очевидне для носіїв вихідної мови, виявляється малозрозумілим або взагалі незрозумілим для носіїв мови перекладу. Перекладач, природно, не може не брати цей аспект до уваги в своїй діяльності. Він повинен зрозуміти те значення, ті смисли, які автор хоче передати мовою оригіналу, і передати його мовою реципієнта, зберігаючи при цьому додаткове забарвлення, адже у такий спосіб він засобом перекладу здійснює необхідний вплив на одержувача інформації, адже це $є$ неодмінною умовою досягнення повної перекладацької адекватності.

На особливу увагу заслуговує необхідність подальшого комплексного вивчення конотативного компонента значення, можливого лише в рамках дисципліни, яка носить синтезуючий характер, наприклад, перекладознавство. В якості дослідницької перспективи значущим представляється розробка адекватних методик експлікації конотацій (еквівалентних конотацій) на різних рівнях мови як одного з визначних факторів еквівалентного перекладу.

\section{REFERENCES}

[1] A.F. Arhipov, Samouchitel' perevoda s nemeckogo yazyka na russkij, Vyssh. shk., Moskva, 1991, 255p .

[2] H. Bußmann, Lexikon der Sprachwissenschaft, 3. aktualisierte und erweiterte Aufl. Alfred Kröner Verlag, Stuttgart, 2008, 783 p.

[3] B. Felicitas Birk, Konnotation im Deutschen Eine Untersuchung aus morphologischer, lexikologischer und lexikographischer Perspektive Inaugural-Dissertation zur Erlangung des Doktorgrades der Philosophie an der Ludwig-Maximilians-Universität München, 2012, 1172 p.

[4] V.I. Goverdovskij, Dialektika denotacii i konnotacii, Voprosy yazykoznaniya 2 (1985) 7179.

[5] M. Kadric, K. Kaindl, M. Kaiser-Cooke, Translatorische Methodik, 4. Auflage, Facultas, Wien, 2010

[6] V.A. Karpiuk, Konotatyvnyj aspekt dijeslivnoji nominaciji u suchasnij nimecjkij movi, Filologhichni studiji: Naukovyj visnyk Kryvorizjkogho nacionaljnogho universytetu 12 (2015) 47-55.

[7] V.A. Karpiuk, Ekvivalentnist perekladu i yii kontekst, in: "II Tavriiski filolohichni chytannia": Materialy mizhnarodnaoi naukovopraktychnoi konferentsii, m. Kherson, 20-21 travnia 2016, Helvetyka, Kherson, 2016, pp. 8283.

[8] W. Koller, Einführung in die Übersetzungswissenschaft, 4. völlig neu bearbeitete Auflage. Quelle \& Meyer, Heidelberg, 1992.

[9] W. Koller, Einführung in die Übersetzungswissenschaft, A. Francke, Tübingen, Basel, 2011, 349 p.

[10] T.R. Kyiak, A.M. Naumenko, O.D. Ohui, Perekladoznavstvo (nimetsko-ukrainskyi napriam), Kyivskyi universytet, Kyiv, 2008, $543 \mathrm{p}$.

[11] C. Nord, Textanalyse und Übersetzen, Julius Groos Verlag, Tübingen, 2009.

[12] V. Ptáčníková, Zu theoretischen Aspekten des Übersetzens und der Übersetzbarkeit, Informatologia 41 (2008) 122-131. 
[13] K. Reiß, H.J. Vermeer, Grundlegung einer allgemeinen Translationstheorie, Gunter Narr Verlag, Tübingen, 1991.

[14] E.G. Rizel', Stilistika nemeckogo yazyka, Vyssha shkola, Moskwa, 1975, 316 p.

[15] V.I. Shahovskij. Ehmotivnyj komponent znacheniya i metody ego opisaniyayu, Izd-vo GU, Volgograd, 1983, pp. 13-14.

[16] R. Stolze, Übersetzungstheorien, 6. Auflage. Narr Francke Attempto, Tübingen, 2011.

[17] V.N. Teliya, Konnotativnyj aspekt semantiki nominativnykh edinic yazyka, Moskwa, 1986, $141 \mathrm{p}$.

[18] W. Wills, Übersetzungswissenschaft: Probleme und Methoden, Klett, Stuttgart, 1977. 